\title{
The Voice of Women between Aphra Behn and Oliver Goldsmith
}

\author{
Asst.Prof. Dr. Rasha Abdulmunem Azeez Alabdullah \\ College of Languages/ University of Baghdad \\ Baghdad, Iraq \\ Department of English
}

DOI: $10.37648 /$ ijrssh.v10i03.030

Received: $18^{\text {th }}$ June, 2020; Accepted: 21st July, 2020; Published: $14^{\text {th }}$ August,2020

\begin{abstract}
Behn and Goldsmith are among the prominent dramatists of Restoration period. This research article discusses their early feminist trends in two well-known comedies written by them. Behn's The Rover presents a young heroine who is sent to convent by her brother to be a nun. She refuses her brother's decision and she appears as a young woman who is aware of her desire to love. Goldsmith's play She Stoops to Conquer presents another female character who attempts to reform a nervous young man (Marlowe) who does not know how to behave naturally with women. This paper proves that feminist ideas have appeared clearly as early as the Restoration Age.
\end{abstract}

Keywords: Femenism, women, love, comedy, stereotype, freedom

\section{INTRODUCTION}

Aphra Behn (1640-1689) and Oliver Goldsmith (17301774) are among the prominent dramatists of Restoration period, although Goldsmith is considered late Restoration or early $18^{\text {th }}$ century writer. Aphra Behn, as a female writer, wrote and was concerned about female problems and sharing women's suffering of patriarchy (Gill 1994, 138). Goldsmith, on the other hand, restored the genuine laughing comedy to the theater: "for certain time [genuine comedy] had been disguised in the cast-off clothes of her stately and prudish sister [t]ragedy, which suited neither her stature nor her complexion. Goldsmith gave her a new gown that fitted her, and made her again look charming" (Gaussen 1993, 86). Both Behn and Goldsmith have their contributions to comedy or drama. This paper will discuss their early feminist trends in two well-known comedies written by them.

Behn's The Rover (1677) presents a young heroine (Hellena) who is sent to convent by her brother to be a nun. The hero of the play is the rake Willmore who loves Hellena. Hellena refuses her brother's decision and she appears to the reader as a young woman who is aware of her desire to love. A conflict is created because of Hellena's status as a nun, because of Willmore's relation to the prostitute Angelica Bianca, and because of Willmore's disbelief in marriage and virtue. For him, any woman is something that he may purchase and enjoy for a temporary time. For him, love is not a vow that he may give to a woman he admires, but it is a moment of pleasure. Goldsmith's play She Stoops to Conquer (1773), on the other hand, presents another female who attempts to reform a nervous young man (Young Marlowe) who does not know how to deal naturally with upper-class ladies, while he acts like a rake with low-class women. Kate Hardcastle does not refuse her father's arrangement to make her marry Marlowe, and she does not try to run away like many ladies in the period who simply escape to get rid of an arranged marriage that they dislike. Instead, she decides to disguise as a barmaid and shows Marlow how to get rid of these two extremes and to be natural. This paper shows two female attempts to act wisely and bravely in a time when women were inferior to men and in a society that characterized by male dominance. Kate puts a clever plan to educate the man that will be her husband, and Hellena faces bravely the rover Willmore and his rakish behavior. Disguise is implied in both cases: Kate as a 
barmaid and Hellena first disguised as a gipsy then as a man who comes to inform Angellica a message.

First, I will show the social background in which both women are acting, concentrating on the female status during Restoration period in general and some early simple feminist approaches. Women of Restoration have a limited role in society. They were seen within the uniform of a wife and a mother only. They were under the control of a father or an older brother before marriage and under the control of a husband after marriage. Women became a stereotype, and a generalization: "[m]ost women have no characters at all" (qtd. in Rogers 1982, 39). This statement can be used simply to define women at the time.

Women got limited opportunities of education. A fortunate girl might get a good education at home by a father or a brother who took an interest in teaching her like Elizabeth Carter. Otherwise, girls or women would spend their time going for walks or reading some easy, silly books. Education and work of women were seen unimportant for society, and even female workers got cheaper payment than male workers. In fact, most learned women at the Restoration time were usually used in drama as "targets of satire, either goodnatured or caustic" (McDonald1979, 46). However, women's education started to be seriously considered as something important for the progress of society through individual attempts in mid 1760s and 1790s by such male and female writers as Mary Astell and Daniel Defoe and then by Hannah More and Mary Wollstonecraft . The latter emphasized the importance of women's education, and she stated that education would allow women to be independent and neither be blindly obedient wives nor bad mothers (Wollstonecraft 2009, pp. 186-187). Hannah More was an example of a woman who got the chance to fulfill herself satisfactorily because her father provided her with well education. She had a lot of famous works that gained high praise, and she organized and supervised many schools (Rogers 1982, 3334). Such female figures

significantly helped women by devoting so much attention to their concerns and constantly exhorting them to behave according to their nature as rational beings; they insisted that women had minds that should be developed, and they gracefully imparted a great deal of cultural information. (Rogers 1982, 30)

Although some women writers, like Charlotte Turner Smith, faced some economic and personal pressures that made their achievement limited, they demonstrated that women could write professionally in all genres as men and "publishing [woman's] work could be consistent with the utmost virtue and femininity" (Rogers 1982, 27). This result was consistent with improving women education. The more education was provided to women, the wider recognition would be of creative women writers.

Aphra Behn is considered the first professional woman writer in England. She was the only woman whose plays were performed regularly on the London stage at that time, and she was the only one who catered successfully the public taste at a time when a male monopoly on all aspects of theater was only just beginning to be challenged ( Spencer 1993, 88). She indicated that she could write as well as men and that she had the right to be valued equally. She attacked those who sneered at female writers (Rogers 1982, 97). Inequality for women, female powerlessness, forced marriages, and sexual double standard were among the themes that Behn treated in her drama. She looked for a community with a new social order where women were defined in women's terms not in men's terms. In men's terms, women were seen as a homogeneous group separated from humanity in general (Rogers 1982, 38), while they were seen, in women's terms, as a group that has creative potentials.

Behn made her heroines engage in a sexual conquest, and they almost always linked sexuality with wit. Behn employed a discourse on feminine desire; however, her drama remained in conformation with Restoration conventions of masculine privilege and the female sexual behavior would not overstep its bound, employing marriage to wrap up a happy ending. Behn showed an early feminism. She is described by Pat Gill as a "profeminist" $(1994,138)$ because she treated women issues in her plays and recognized the oppression that women in her time underwent. Her heroic females were all clever, goodnatured, tolerant of their gallants' misbehavior, and knowledgeable about life and love (Gill 1994, 141). Behn seemed to be upset with the sexual freedom in the Restoration society that appeared to be a double-edged concept. Men were free to be rovers while female desire was considered a taboo and even "vulgar"(Stewart 2010, 11). Generally speaking, female sexuality was not a consideration in the plays written by men. Male writers illustrated the female sexuality in terms that serve to confirm the virile capacity and amorous success of a male seducer (Gill 1994, 141-142) and not as real emotions and rights.

\section{HELLENA}

Behn introduces from the very beginning of her play The Rover a self-assertive heroine to reveal that the main, important issue in her play is a female issue. Hellena refuses the nunnery and pursues her emotions:

Hellena. I never was a lover yet; but I begin to have a shrewd guess what 'tis to be so, 
and fancy it very pretty to sigh, and sing, and blush, and wish, and dream and wish, and long and wish to see the man, and when I do, look pale and tremble. (1.1.9-12)

The play is set during carnival time that allows disguise and this gives freedom to the disguised woman by transforming her identity through disguise. Hellena disguises herself as a gipsy, liberating herself of her brother's patriarchal control and claiming that she will appeal to her man: "I'll have a saint of my own to pray to shortly. If I like any that dares venture on me" (1.1.143-144). For Hellena, the disguise or the mask is "a form of resistance to the oppression of feminine desire. Masked, she believes she will rule herself... and her own destiny" (Hutner 1993, 106-107). However, Hellena is aware that this freedom promised by her mask will function within the context of the seventeenth-century marriage market and its class-based assumptions about feminine value (Hutner 1993, 107). Thus, Behn is presenting a female freedom and insistence but not the ones that will transform her to a prostitute or crossing the upper-class rules.

In the carnival, Hellena meets Willmore. The masculine figure Willmore is the rover of the play. He is so handsome and attractive, yet he is bully and drunken. He wants to use women without considering their feelings or rights, and he looks to enjoy their bodies without offering them any return. He starts to seduce Hellena, ridiculing her status as a nun. Hellan's answers to Willmore reveal her self-confidence and a virtuous awareness: "Helena. Why must we be either guilty of fornication or murder if we converse with you men? And is there no difference between leave to love me, and leave to lie with me?" (1.2.194-196). In fact, she achieves her conquest of Willmore through linguistic manipulation by refusing to give herself completely to him. A distinct example of her way of handling the conversation with Willmore is when he makes an evil use of the Biblical story of Jephtha's daughter and how she died lamenting her virginity. He hopes to convince Hellena that virginity is worthless and will lead her to distress. He wants to give his seduction a kind of religious or legitimate frame in order to make his seduction to Hellena successful:

Willmore. A nun! Oh how I love thee for't! There's no sinner like a young saint.

Nay, now there's no denying me: the old law had no curse, to a woman, like dying a maid; witness Jephtha's daughter.

Hellena. A very good text this, if well handled; and I perceive, Father Captain, you would impose no severe penance on her who were inclined to console herself
She answers him so calmly. She agrees to Willmore's idea but in a tricky way. She neither intends to remain virgin nor she will lament that, but she prefers marriage that is also a lawful way for virginity failure (Spencer 1993, 86). Willmore, first, refuses strongly the idea of marriage:

Willmore. Hold, hold, no bug words, child. Priest and Hymen? Prithee add a hangman to 'em to make up the consort. No, no, we'll have no vows but love,

Marriage is as certain a bane to love, as lending money is to friendship:

I'll neither ask nor give a vow. (5.1. 445-451)

And Hellena answers him, saying: "..., what shall I get? A cradle full of noise and mischief, with a pack of repentance at my back? Can you teach me to weave incle to pass my time with?" (5.1.456-458). Behn has perfectly formed the quality of self-awareness in Hellena (McDonald 1979, 196). Hellena wants to get rid of the nunnery and her virginity but through her own terms: through marriage (Stewart 2010, 102). By her witty answers and even by using her own fortune to attract Willmore, she succeeds, finally, in trapping the rover. By the end of the play, Willmore admits that "thou'rt a brave girl, and I admire thy love and courage" (5.1. 570-571).She, finally, achieves a victory that is described as a "victory [that] is conventional and entirely within the old law that sees marriage as woman's success" (Spencer 1993, 87).

The witty heroine enters the marriage with eyes open. She may not reform her rover but she manages a victory over him and, also, over her father's and brother's authority and manages to discard the prospect of the nunnery. Hellena knows her value as a woman. She rejects to be a nun, and, at the same, time she rejects to be her man's mistress. Her weapon is her wisdom and language, and her final speech with Willmore about love and marriage makes him approve to her claims. Margaret Lamb McDonald describes that vividly by saying, "[i]t is the Restoration dramatist's ability to portray a complex heroine with such a depth of serious feeling beneath her casual, playful exterior" $(1979,197)$.

As have been alluded before, Behn must return at the end of her drama to the social standard; she seems to accept men's emotional domination as natural and proper thing (Rogers $1982,99)$. She cannot really break the legitimate system of the society or the orderly transfer of property from a male (a father or eldest son) to another male (a husband) (Finke 1993, 28). That is why Behn resorts to marriage as the happy logical ending.

before she took orders. (1.2. 170-176) 


\section{KATE}

She Stoops to Conquer is also investigated as a pre-feminist text. Kate, the heroine, has the ability to conquer her future husband and teach him how to acquire a stable identity in front of upper-class women. Goldsmith empowers her, unlike other girls of the time, of the arranged marriages to show her suitor how to appreciate her as a woman. Her suitor, Marlow, is another rake like Willmore. Marlow would prey on a low-class woman, but he acts timidly and nervously in front of an upper-class woman. Kate's discourse to reform this condition is a discourse of honesty and virtue under the guise of a barmaid. She demands certain qualities in the man she will marry, and she needs to assert these qualities in him; otherwise, to be passive is to allow herself to fall into what is called the "horse-trading of arranged marriage" (qtd. in Brooks 1992, 40). Kate decides not to be silent and to escape the misery of the bad marriage. This misery of a daughter is described accurately by Mary Astell, who is one of the early English feminists:"to be denied one's most innocent desires, for no other cause but the Will and Pleasure of an absolute Lord and Master, whose Commands she cannot but despise at the time she obeys them; is a misery that none can have a just Idea of, but those who have felt it" (qtd. in Brooks 1992, 40). Kate has the voice of courage and persistence that most women in her age lack:"a woman should have a voice in choosing the man who would control her life" (Rogers 1982, 1). Kate personifies the assessment of early feminism made by Rogers here, and Kate has this voice that she uses to recreate the masculine spirit of Marlow (Brooks 1992, 41).

Like Hellena, Kate knows her value as a woman, and she knows that her value goes beyond her beauty and wealth and it extends to her intellect. In Christopher K. Brooks' opinion, "[i]t is a virtual axiom of feminist thought that patriarchal men must be re-educated, and that women must assume the role of educators" $(1992,41)$. Kate assumes this role. She says after her first meeting with Marlow, "I'm certain he scarce looked in my face the whole time. Yet the fellow, but for his unaccountable bashfulness, is pretty well, too. He has good sense, but then so buried in his fears, that it fatigues one more than ignorance. If I could teach him a little confidence,..."(Goldsmith 1951, 26). And she says when deciding on her plan of disguise:

Miss Hardcastle. In the first place, I shall be seen, and that is no small advantage to a girl who brings her face to market. Then I shall perhaps make an acquaintance, and that's no small victory gained over one who never addresses any but the wildest of her sex. But my chief aim is to take my gentleman off his guard, and like an invisible champion of romance examine the giant's force before I offer to combat. (Goldsmith 1951,39)

So, Kate likes Marlow and she evaluates his good nature, but she thinks he needs reformation, and this reformation is Kate's combat or challenge. Brooks finds Kate is willing to marry, and she uses the term "market" in her speech above because she is aware that she must play the hostess of her father's choice and bring herself in the marriage scene; however, she does re-shape the market through wearing the feminine cloak of invisibility (invisible to Marlow as Kate Hardcastle) (Goldsmith 1951, 44).

Kate and Marlow meet and converse a couple of times before he knows her real identity in act five. Kate shows him how a barmaid acts wisely and virtuously. She rejects his attempts to approach her and kiss her. Marlow admires her modesty and beauty and he says, "[t]his simplicity bewitches me ... your partiality in my favor, my dear, touches me most sensibly" (Goldsmith 1951, 50). And later he confesses:

Marlow. Your beauty at first caught my eye; for who could see that without emotions? But every moment that I converse with you, steals in some new grace, heightens the picture, and gives it stronger expression. What at first seemed rustic plainness now appears refined simplicity. What seemed forward assurance, now strikes me as the result of courageous innocence and conscious virtue. (Goldsmith 1951, 66).

Kate is confident of that outcome. At the end, as Marlow knows her reality, she announces addressing him in front of his father and her father and says, "[i]n which of your characters, sir, will you give us leave to address you? As the faltering gentleman with looks on the ground, that speaks just to be heard, and hates hypocrisy; or the loud, confident creature... Ha! ha! ha!" (Goldsmith 1951,67). Her final laugh expresses her victory. A last laugh of success of one who has clearly conquered the whole situation (Brooks 1992, 47). Marlow has learned to see Kate as she really is. He reevaluates her personal assets, and, in doing so, he re-defines his own (Brooks 1992, 46). She teaches him how to speak to a woman, and how to speak sincerely: "she gradually brings his masculinity more in line with her definition of femininity" (Evans 2011, 61).

Kate asserts also her independence and intelligence as a woman with her father. When Mr. Hardcastle converses with Kate about Marlow's behavior and impudence (Marlow thinks that Mr.Hardcastle's house is an inn that is why he acts strangely most of the play), she does not say directly that she has another opinion and that she is trying to change Marlow's language. Kate indirectly defends her view and 
indirectly debates with her father. She says first, "I find such a pleasure, sir, in obeying your commands, that I take care to observe them without ever debating their propriety" (Goldsmith 1951, 32). And then she says,"I hope, sir, a conversation begun with a compliment to my good sense won't end with a sneer at my understanding?" (Goldsmith 1951, 34). Kate makes her father assume her obedience and submission to his command and that she does not offer any debate, but in fact she does that in a smart way. She offers a debate about this point and convinces her father to give Marlow another chance. In her speech above, Kate "reminds her father of her intellectual capabilities, in effect flattering his patriarchal instincts in order to gain time to decide her own fate" (Brooks 2014, 43). Thus, Kate appears here as an educator even to her father, creating an understanding between her and her father. He says then, "[w]ith her, a smooth face stands for good sense, and a genteel figure for every virtue" (Goldsmith 1951, 34). Kate's skill of conversation tells about an intellect or knowledge. The text of the play discloses for the reader that she used to read some decent books. When she speaks with her own maid about her plan to dress herself as a barmaid, she says,"[t]ell me, Pimple, how do you like my present dress? Don't you think I look something like Cherry in the Beaux Stratagem?" (Goldsmith 1951, 38). Reading Farquhar's comedy The Beaux Stratagem (1707), Kate seems to be a good reader and that she has some good knowledge and background about things around her. She knows how maids are dressed and how they look like. Kate proves to be a natural woman who finds a method to please her father, her future husband, and most importantly herself. Prudence emerges here against male power and seduction. At the closing of the play, Marlow calls Kate "my little tyrant" ( Goldsmith 1951, 69) as she gains authority to express herself:

Kate is not caught in the trap of an unhappy forced marriage; she is not stripped of her identity or character; she is clearly not silent. Thus, though the play's title indicates the self-diminishment required of Kate, the proposal scene ultimately depicts Marlow on his knees, eloquently asking Kate, standing over him, to be his wife. That this happy ending has come about is all to Kate's credit. That Marlow is able to speak honestly and confidently is the true mirth of this "laughing comedy," a comedy in which "She" represents any woman of sense and virtue who has overcome, has "conquered," the economic, romantic, and marital woes constructed by the patriarchal world about her. (Brooks 1992, 50)

\section{CONCLUSION}

This paper sheds the light on two female characters who appear in two different plays. One play appeared during the 1660 s and the other during the 1770s. Although Goldsmith's play is considered a late Restoration play and has appeared after a considerable time after Behn's The Rover, both plays manifest an emergence of early feminist trends and a development of women self-determination. Not any fair woman in the Restoration period or drama has an introspective capability like Kate and Hellena. Some women seem totally unaware of their own emotional needs and unable to recognize their own motivations. Kate and Hellana have this awareness and know their goals. They realize their goals wisely and confidently. Both female characters discussed here prove their identity, wisdom, and strength towards a father and a lover or a future husband.

Some opinions consider Behn's feminist approach clearer and more intensified than Goldsmith. McDonald finds Goldsmith's attempt to revive the laughing comedy fail to restore the "the vivacious and independent young woman who once dominated Restoration comedy" (1979, 243). However, the character of Kate reveals the opposite because she reminds the reader of the independent woman that he has seen in Behn's plays. Kate's prudence and sense make her stand out as Goldsmith's essential early feminist (Brooks 1992, 49). The importance of including Goldsmith's play in an argument of early feminism here results from the fact that the play is a male text, which indicates that there were some male writers who cared to create a strong female character. As Brooks puts it:"[t]he strength of Kate Hardcastle's character has always been one of the 'charms' of She Stoops to Conquer" (1992, 40). This is similar to Behn's charm female characters who are truly active and they display wit and intellect, but Behn emphasizes more than Goldsmith the sexual desire of her female characters and how social standards judge differently male and female behaviors. Behn's plays also show how this female behavior troubles the sexual politics of the world that women inhabit by demonstrating a sexuality that is responsive to their own desire, as well as to the strict social constraints that bind it (Lowe 2007, 92).

It is suitable here to mention that Behn has been ignored by critics and historians for a very long time. Since her death in 1689, Behn has been marginalized and her plays, like The Rover, are mostly considered of a doubtful morality. Her concern of women freedom is seen before as disgrace for womanhood. Significantly, she has received recently with the great wave of feminism a huge attention during the past years starting from the mid-twentieth century, and critics consider her "the foremother of British women's writing" (Hutner 1993, 1). Her works have been re-evaluated, new 
editions of her works become available, and her biography is re-studied as a necessary document to understand her works. Such heroines as Hellena and Kate are examples of the independent women in Restoration drama. They are blends between intelligence and morality that take them out of a London drawing room and enrich the concept of the heroine in English drama in general and Restoration drama in particular.

\section{REFERENCES}

Brooks, Christopher K. 1992. "Goldsmith's Feminist Drama: She Stoops To Conquer, Silence And Language." Papers On Language And Literature: A Journal For Scholars And Critics Of Language And Literature 28, no. 1.

Evans, James.2011. "'The Dullissimo Macaroni': Masculinities In She Stoops To Conquer." Philological Quarterly 90, no.1.

Finke, Laurie.1993. "Aphra Behn and the Ideological Construction of Restoration Literary Theory." Rereading Aphra Behn: History, Theory, and Criticism, ed. Heidi Hutner, 17-43. Charlottesville: University Press of Virginia.

Gaussen, Alice C.C. 1993. "She Stoops to Conquer." Goldsmith Interviews and Recollections, ed. E.H. Mikhail, 74-84. Alberta: St. Martin's Press.

Gill, Pat.1994. Interpreting Ladies: Women, Wit, and Morality in the Restoration Comedy of Manners. Athens: The University of Georgia Press.

Goldsmith, Oliver.1951. She Stoops to Conquer: or Mistakes of a Night. Wheeling: Halan Davidson, Inc.

Hutner, Heidi.1993. "Revisioning the Female Body: Aphra Behn's The Rover, Part I and II," ed. Hutner,102-121.

Lowe, Leah. 2007. "Gender And (Im)Morality In Restoration Comedy." Theatre Symposium 15 92, no.106.

McDonald, Margaret Lamb. 1979. The Independent Woman in the Restoration Comedy of Manners, ed. James Hogg. Salzburg: University of Salzburg Press.

Rogers, Katherine M. 1982. Feminism in Eighteenth-Century England. Urbana: University of Illinois Press.

Spencer, Jane.1993. "Deceit, Dissembling, all that's Woman: Comic Plot and Female Action in The Feigned Courtesans," Hutner, 86-102.

--- . 1995. Introduction to The Rover and other Plays by Aphra Behn, vii-xxii. New York:Oxford University Press.

Stewart, Ann Marie 2010. The Ravishing Restoration: Aphra Behn, Violence, and Comedy. Selinsgrove: Susquehanna University Press.

Wollstonecraft, Mary. A Vindication of the Rights of Woman, ed. Deidre Shauna Lynch. New York: Norton \& Company. 